\title{
La inmediatez de la validación y la pérdida de la autonomía
}

\author{
Autor: Pedro Ernesto Vargas, M.D., F.A.A.P. \\ Neonatólogo y Pediatra
}

Entro al ascensor -puede ser el del edificio donde vivo, el de la oficina donde trabajo, el de cualquier otro edificio- y la imagen es la misma, una y otra vez, un día y otro. Todas las personas excepto una, cuando no todas, sean 5 o 7 o 3 los que viajan en ese cubo cerrado y frío, están conectados a su celular. Ni siquiera atienden la señal del piso donde se ha detenido brevemente el ascensor. Incluso, piden perdón cuando les queda algo de orgullo, para interrumpir el cierre programado de la puerta del mismo y no tener que apearse un piso más arriba o más abajo.

Lo mismo hacen frente al timón del auto que conducen, cruzando la calle sobre una cebra o donde le venga en gana, estropeando la entrada a un comercio, deteniendo el curso de los peatones en un cruce o de quienes trotan en un parque. Total, hoy la inmediatez es como la insoportable levedad del ser, tan volátil como atropelladora. ¿A dónde nos lleva todo esto?

El teléfono celular, portátil y con el cual se toma fotografías sin saber absolutamente nada de fotografía, las redes sociales, que bien llamo antisociales, la información a la distancia y velocidad de los dígitos han engendrado todos un monstruo: la inmediatez. Ahora, si estoy cerrando la puerta de la cocina prefiero llamar a la mucama por teléfono para recordarle hacer la cama o que vea en la refrigeradora, si hay o no suficientes huevos o pan. Ya no me importa memorizar un listado de 3 o 5 legumbres que comprar o enseres de la casa; cuando llegue a comprarlas llamaré por el celular para que me dicten lo que no me interesa siquiera recordar. Al doctor lo llamo para preguntarle dónde comprar el acetaminofen y cómo me lo tomo, como si nunca antes lo hubiera tomado; y, de paso, le pregunto si va a estar en la ciudad el fin de semana por si lo necesito desde la playa.

Y, qué decir de la niña con quemaduras de 3er. grado por los bombardeos a la población en Siria con napalm, sentada frente a una cámara de celular que retrató su piel desgarrándose, su rostro inocente preguntándose y, atrás, se siguen oyendo los ruidos de las bombas y de los gritos de la gente. O, el padre y la niña abrazados y ahogados en la orilla del Rio Grande, donde intentaban buscar vida nueva como inmigrantes, engañados y traficados por inescrupulosos seres humanos, que yo bien llamo inhumanos y criminales. $Y$, estas escenas ser repiten todo el día, todas las horas, cada 30 minutos y a cada minuto para que de tanto verlas ya no las veamos, ya no las extrañemos, ya no las sintamos.

O, el vocabulario soez, la denuncia falsa, la noticia "fake", la bochornosa descripción de la vida privada de alguien que fue importante para desbancarlo de su lugar, que lucen toda clase de seres de la especie humana, buscando risas, aplausos, más vocabulario altisonante y vulgar, validación. Porque cada vez que tengo un "like", me están validando como quien produce opinión, como un individuo influyente en la sociedad o suciedad, como prefiero decirle, como "influencer". 
Y, ¿a quién le interesa todo esto? Al mercado. Un mercado de comerciantes con los seres humanos. Un mercado para aflorar lo más bajo de una persona. Un mercado para enriquecer a unos cuantos y empobrecer a millones de personas. La toxicidad llegará a tal punto que te sentirás enfermo antes de enfermar a muchos otros, y la adicción es tal que 6 horas sin Facebook o sin Twitter o sin Instagram son una eternidad. Prendes y apagas la pantalla del celular buscando la señal que ha desaparecido. Te arrancas los pelos de la cabeza, te comes las uñas, pateas las patas de la mesa o escritorio, gritas, te enfadas con tu mujer y tus hijos. Todo en 6 horas de "falla mundial de la red social". Una forma de "flash depression", de psicosis aguda. ¿Quién te valida ahora? ¿Te desconectaron del mundo? Tus neuronas piden más dopamina porque la droga escasea.

Hemos perdido libertad, la esclavitud a la que nos relega la adicción a las nuevas formas de comunicación nos está llevando al cansancio, ya no solo laboral sino al cansancio de vivir. La sociedad del cansancio se yergue y nos devora en una pasividad absoluta y tenebrosa. Nos cansó la urgencia de la productividad a como diera lugar, pasando por encima de los otros, o por debajo escondidos para sorprender.
El rendimiento se mide por el número de víctimas que dejamos atrás, y ni siquiera nos damos cuenta que somos también una de esas víctimas del rendimiento.

Hemos perdido autonomía, no tenemos opciones porque quienes conocieron la forma de controlarnos, quienes cuentan por millones los ingresos de sus inventos para interconectar y desconectar, nos tienen "el pedigree" -como decía un tristemente célebre personaje- para recetarnos libros, ropas, viajes, parajes, novios y novias, bebidas, restaurantes, medicina alternativa, autos, moto, aviones, barcos, lanchas, yates. El consumismo material y salvaje que acaba con esta civilización.

Entre las condiciones necesarias para el desarrollo de la autonomía, de la identidad personal, en el niño están el que conozca que la inmediatez no es el patrón para la conducta, que todo requiere un tiempo, que la gratificación puede y debe ser tardada, y, que no sea manipulado externamente, que no esté expuesto a la coerción. Hoy, el más serio obstáculo para crear autonomía es esta forma incoherente de vivir a la que nos vienen llevando los creadores y dueños de las redes sociales, la ignorancia a las que nos condenan las noticias falsas, y la inmediatez de las respuestas y validaciones que exigimos ciegamente. 